\title{
Aspects of Algerian Medical Translation
}

\begin{abstract}
:
The aim of this article is to throw light on some aspects of the English-Arabic Medical translation which belong to the most significant area of difficulty met by the Algerian university students, especially in terms of style and terminology. It also attempts to draw attention to some Algerian students' misconceptions related to the translation of English Medical texts into Arabic.
\end{abstract}

Keywords: Medical Translation, difficulty, style, terminology, misconceptions.

\section{Nassima BENCHABANE}

Faculty of Letters and Languages Department of English University of Mentouri Constantine (Algeria)

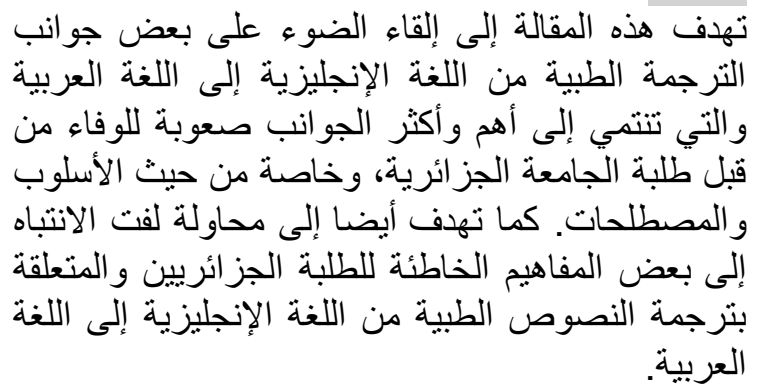

\section{Introduction}

Thanks the development of science and technology, new English words emerged to express new concepts, techniques and inventions. This development has brought to the Algerian translators serious linguistic problems to express this newly founded terminology for which the Arabic equivalent is difficult to find. Culler (1976:21-22) states that: "one of the troublesome problems of translation is the disparity among languages". 
The bigger the gap between the SL and the TL, the more difficult the transfer of message from the former to the latter will be. Farghal and Shunnaq (1999:210) point out that: "the major problem facing translators at present is terminology standardization and dissemination in the sphere of science and technology".

\section{Research questions}

The present article attempts to answer few questions pertaining to students' performance in translating English medical texts into Arabic in the department of Foreign Languages at the University of Constantine.

- What is the current situation of the translation of medical texts from English into Arabic in Algeria?

- What are the strategies used by Algerian first years master students in their translation of medical texts?

- What are the terminological problems encountered by the Algerian students in their translation of medical texts?

- What are the possible strategies that may help Algerian students improve their Hypothesis: translation of medical texts?

If the Algerian students of the University of Constantine1 manage to develop their scientific repertoire and follow an appropriate strategic approach, their translation of medical texts will be efficient.

\section{Scientific and Medical Translation}

Scientific texts, in general, and medical texts, in particular, unlike the other types of texts, contain unfamiliar content and text structures, heavy conceptual and theoretical aspects and a special vocabulary. The purpose of medical texts is to help uninformed and misinformed readers receive information and construct meanings about specific terms and expressions for describing diagnoses, diseases, body organs and symptoms, using an expository approach, words (concept labels) with specific meanings, complex and interrelated sentences, and specific text structures (description, collection, problem/solution, causation). Carrol (1966) measures the quality of translation of scientific texts by the rate of "informativness". Yet, Nida (1964:223) in his discourse on scientific translation, argues that:

If, however, the translation of scientific texts from one language to another participating in modern cultural development is not too difficult, it is not surprising that the converse is true-that translating scientific material from a modern Indo-European language into a language largely outside the reach of Western science is extremely difficult.

Pinchuck (1977:19) claims that "vocabulary is the most significant linguistic feature of scientific and medical texts". He maintains that "many scientists are delighted by the fact that their specific jargon makes their field unintelligible for lay people and outsiders, leaving the impression that only experts can understand the deep mysteries involved". Therefore, there is a dichotomy and controversy surrounding the importance of style and terminology in the translation of scientific and Medical texts. 


\section{Translation of Medical Texts in Algeria}

The act of translation is guided by certain strategies. One of these strategies accounts for the systematic differences between the English and the Arabic languageswhile another depends on the type of language used in any individual text. Both strategies are taught to and used by the Algerian students in their translation of English medical texts into Arabic. However, upon the examination of the Algerian sociolinguistic situation following the independence, Algeria is considered to fit what Fishman (1972) describes as a "type B nation". Type B nations are called "uni-modal" and are characterized by an indigenous language with a literary tradition (Classical Arabic or Modern Standard one). However, the complex linguistic background of the Algerian students, which consists of: the Algerian dialect, standard Arabic as their first language (L1), French as their second language (L2) and English as their third language (L3), makes difficult to render the message delivered byoriginal medical texts, especially in terms of style and terminology, where the gap between English and Arabic is omnipresent. Bouchikhi and Mustafa El Hadi illustrate this lexical gap between English and Arabic in the example of the word "electrocardiogram(1)", whose translation into Arabic corresponds to the term“"مخطط كهربية القلب", andincludes three Arabic words that cannot be dissociated in order to preserve its meaning. Another example is the word acetylcholine ${ }^{(2)}$ whose Arabic transliteration is: "أستيلكولين". The transliteration of this word is the result of the absence of the equivalent Arabic term to the English original word. These are just a few generic examples of the complexity and depth of the Arabic language; theyshow how difficult it can be for an Algerian student to translate medical terms, especially for those who are not specialized in the field, and how their mistranslation can influence the whole message delivered by the source text. Therefore, the use of an adequate strategy is crucial for a successful translation of medicaltexts. In this respect,O'Malley and Chamot, (1990) insist on the fact that the students' performance can be improved by following certain strategies and that the appropriate use of strategies enables learners to learn effectively.

\section{Research Design}

\subsection{Subjects}

To examine the Algerian students' translation of English medical texts into Arabic, an English Medical text was administered to a group of 50 Master students, taken from the English department at the University of Constantine 1, to be translates into Arabic. The selection of the group is primarily based on the fact that students at this level have a fairly good command of English after 3 years of intensive study in the English department at the University of Constantine1. The purpose of this test is to depict the students' translation of medical texts, and to elicit the stylistic and terminological difficulties encountered in their translation. In addition, the test attempts to portray the main students' misconceptions of the medical translation.

\subsection{Nature of the Text}

The title of the medical text is: "Functions of the Human Body" taken from the book "Beginning Scientific English" written by D.E. Royds Irmak. It has deliberately been chosen for the following reasons:

a) The Students are familiar with this type of texts during their academic studies, especially in EST sessions.

b) It is of a fair length ( 270 words) to suit the allocated time. 


\subsection{Results and Interpretations}

The analysis of the students' translation of the medical text is described as follows:

3.3.1. The Medical Translation Strategies

The analysis of the source data revealed that numerous translation strategies are adopted by the Algerian students.

- Word-for-word translation: it directly replaces the word in the source language (SL) by an equivalent word in the target language (TL).

- $\quad$ Literal translation: itadheres to the linguistic structure of the SL.

- Free translation: it is primarily interested in communicating the sense of the source text.

- Modification: it is used especially when dealing with two structurally different languages as English and Arabic.

- Transposition: it occurs when the order of words is being modified.

- Paraphrasing: it involves restatements in other forms of words.

All these strategies are essential at various times when dealing with various texts. However, scientific translation requires a particular attention especially when dealing with terminology which may be problematic to the target language. It can be noticed that the specific terminology of this type of text revealed to be painstaking and ardours, and generated serious problems in rendering the source text message faithfully.

An example of the students' difficulty in finding the Arabic equivalent of the English medical term is in the translation of the word slices, which has resulted into 6 different translations as illustrated in table1:

\begin{tabular}{|c|c|c|c|c|}
\hline $\begin{array}{c}\text { Item } \\
\text { No. }\end{array}$ & $\begin{array}{l}\text { The English } \\
\text { expression }\end{array}$ & $\begin{array}{c}\text { The Translated } \\
\text { Forms } \\
\end{array}$ & $\begin{array}{c}\text { No.Of } \\
\text { Occurrences } \\
\end{array}$ & $\begin{array}{c}\text { Suggested } \\
\text { Translations }\end{array}$ \\
\hline $1-$ & & طبقات & 9 & \\
\hline $2-$ & & أغشية & 8 & \\
\hline $3-$ & Slices & خلايا & 20 & شرائح \\
\hline 4- & & شرائح & 7 & \\
\hline $5-$ & & الأجز اء الدقيقة & 4 & \\
\hline 6- & & No equivalentgives & 2 & \\
\hline
\end{tabular}

Table 1: Evaluation of the Students" Translation of the Word "Slices"

It is worth noting, here, that only 11 students were able to grasp the meaning of the word slices, and ended up with a successful Arabic translation as illustrated in items 4 and 5 . Indeed, 7 students translated the word slices as and 4 students translated it as الأجزاء الاققيقة. The remaining tested students rendered it differently, to the extent that not even twocounterpart renderings were observed. In item1, 9 students rendered slices as طبقات which refers to classesrather than slices.In item 2, 8studentsrendered it as أغشية which refers to membrane $^{(3)}$, and in item 3, 20 students opted for the word خلايا, which means cells rather than slices. 
Another example of students' problems in the translation of medical terms is the word tissues, which generated two different renderings as illustrated in table2:

\begin{tabular}{|c|c|c|c|}
\hline $\begin{array}{c}\text { The English } \\
\text { expression }\end{array}$ & The Translated Forms & $\begin{array}{c}\text { No.Of } \\
\text { Occurrences }\end{array}$ & $\begin{array}{c}\text { Suggested } \\
\text { Translations }\end{array}$ \\
\hline \multirow{2}{*}{ Tissues } & No equivalent given & 19 & أنسجة \\
& & 7 & 24 \\
\hline
\end{tabular}

Table 2: Evaluation of the Students' Translation of the Word "Tissues"

As can be seen in the above table, the majority of the students (24) translated successfully the word tissues into أنسجة. Yet, a great number of the students (19) rendered it into خلايا which means cells rather than tissues and 7 students were unable to give an Arabic equivalent of the word tissues.

\subsubsection{Algerian Students' Misconceptions of Scientific and Medical Texts}

\subsubsection{Style Is Secondary in Scientific and Medical Translation.}

Style can be considered as one of the most irritating and frustrating misconceptions for scientific translators. Accordingly, the analysis of the data revealed that the majority of the students show tendency to give priority to terminology over style. Byrne (2006:2) claims that "the view that sees style as secondary in scientific translation is completely unfounded and implies that technical as well as scientific translators have different linguistic and writing skills than other types of translators". He goes on arguing that this problem is perhaps due to the differing opinions of the nature of style and the popular belief that is exclusively related to literature. In addition, literature is considered as an art which is reflected through language; henceforth, if we look at style from a literary point of view, it will not have any place in scientific translation. But, if we regard style as the way we write things, the words we choose and the way we construct sentences, style becomes equally important in any scientific or medical translation. As Zethsen (1999:72) asserts, literary texts "do not hold a monopoly on expressivity and creativity".

\subsubsection{Scientific and Technical Translation is all About Conveying Specialized}

\section{Information.}

Through the analysis of the data, the other noticeable misconception is that there is a common belief among the subject students, that the main concern of scientific and medical translation is restricted to convey information which is not entirely true. This belief is reflected in the students' focus on the translation of medical terms as isolated items. It is unquestionable that the main concern of scientific translators is to make sure that information is conveyed accurately but they are also responsible for ensuring that the information is presented in the correct form, that it is complete and that the information can be used correctly and effectively (Op.Cit.:3). Consequently, the translator's responsibilities include many of those of the technical author. Byrne (Op.Cit:2) emphasizes that:

technical translation involves detailed knowledge of the source and target cultures, target language conventions, text type and genre conventions, 
register, style, detailed understanding of the audiences; whether translators realize it or not, an understanding of how people learn and use information.

\subsubsection{Scientific Terminology}

Yowel and Lataiwish (2000:152) affirm that "one of the misconceptions related to scientific translation, in general, and Arabic translation, in particular, is closely related to terminology". The Algerian students' failure to translate some medical terms has led to use the avoidance strategy by translating the term literally .The avoidance strategy used by the Algerian students can be illustrated in the translation of the word the Endocrine meaning جهاز الغدد الصماء, translated as الإندوكرينجهاز. Purists insist that in scientific translation, the translator should search into the Arabic vocabulary in the hope of finding equivalence for the foreign word before coining a new term. Only if such equivalence is not found then the translator is allowed to coin a new item. Moreover, new established coinages are sometimes severely attacked by critics who claim that they have found in classical Arabic words which convey the same meaning expressed by the new words coined, that is to say, there is no need to try to find new words to express new concepts since they can be found in classical Arabic. The problem is that students, who are not specialized in the medical field, are incapable to look in classical Arabic. In addition, students should build a solid foundation during their academic acquisition of translation skills to be able to look at the equivalent medical terms in the classical Arabic language.

Therefore, the two misconceptions pointed out by Yowel and Lataiwish (2000:126) are first, related to "the linguistic nature of the scientific term, and second, to the scientific repertoire developed by the Algerian students".

They regard the view which claims that the translator is required to search thoroughly for the vocabulary of the language before he is allowed to coin a new term as erroneous, because it sees language as a product rather than a dynamic process. Yet, vocabulary is an open ended component of language and it is not always possible to find items that match the new terms. The only aspect that has to be critically followed by the translator is the coining of new items that correspond to the phonological and morphological rules of the TL. They add that the condition for a successful term is that it is accepted by the user of the language and becomes, gradually, established.

\section{Conclusion}

To sum up, it becomes evident that medical translation is not a simple task that involves the rendering of information in simple words. It rather involves skills, mastery of the two languages (English and Arabic), and broad knowledge of the subject matter. It also requires imagination and talent in coining words that suit the new items, and then the use of a style that helps the reader not only to get the information, but also to understand the principles, concepts, diseases and symptoms that the author wanted to convey.

Therefore, students as future teachers or practitioners in the field of translation must build a solid foundation during their academic acquisition of translation skills, and master efficiently both languages in relation to their different aspects. Further, they should be aware of the importance of style and terminology in the construction of 
meaningful and well structured piece of writing that provides the target reader with the required information in the best way possible. According to Lynch (2001)style is everything about your way of presenting yourself in words, including grace, clarity, and a thousand indefinable qualities that separate the good writing from the bad one.

\section{References}

Carrol, J. B. (1966), An Experiment in Evaluating the Quality of Translations. In Mechanical Translation 9, pp. 55-56

Farghal, M. and Shunnaq, A. (1999) Translation with Reference to English and Arabic. Irbid: Dar Al-Hilal for Translation.

fishman, J. A. (1972). Domains and the Relationships between Micro- and Mcrosociolinguistics. In J. J. Gumperz\& D. Hymes (eds.), Directions in sociolinguistics:The Ethnography of Communication. New York: Holt, Rinehart, and Winston, 435-453

Byrne, J. (2006).Technical Translation.Usability Strategies for Translating Technical Documents.Dordrecht : Springer

Khadija el Bouchikhi and Widad Mustafa El HadiA Semantic Lexicon for Indexing

MedicalTextsinArabicLanguages.

http://www.eahil.net/conferences/helsinki_2008/www.terkko.helsinki.fi/bmf/EAHIL2008/P osterPresentations/El-Bouchikhi-A-semantic-poster.pdf

Korning, Z. K. (1997) Expressivity in Technical Texts - From a translation Theoretical Prespective.Handelshojskoleni Arhus.

Lynch, J.: 2001. Guide to Style and Grammar. www.andromeda.rutgers.edu

Nida, E. A.(1964) Towards a Science of Translating. Leiden: E. J. Brill.

O'Malley and Chamot.(1990). Learning Strategies in Second Language Acquisition. Cambridge: Cambridge University Press.

Pinchuck, I. (1977) Scientific and Technical Translation. London: Andre Deuch,.

Royds-Irmak, D. 1978.Beginning scientific English:book 1.

Yowel, Y.A. \&Lataiwish, M.S. (2000).Principles of Translation.Libia: Dar AnnahdaAlarabiya.

Notes:

1-Electrocardiogram: a graphic tracing showing the variations in electric force which trigger the contractions of the heart: it is used in the diagnosis of heart disease. Webster's New World College Dictionary 2009

2-Acetylcholine: A white crystalline derivative of choline that is involved in the transmission of nerve impulses in the body.Webster's New World College Dictionary 2009

3-Membrane:A thin, pliable layer of tissue covering surfaces or separating or connecting regions, structures, or organs of an animal or a plant 